\title{
RUSSIAN REGIONS: ONGOING SLOW-ROLLING CRISIS ${ }^{1}$
}

\author{
N.Zubarevich
}

In Q1 2016, the regional view of the crisis changed insignificantly. Decline of population's income and consumption posted in the majority of regions remain the most acute issue. The mumber of regions which register ongoing investment decline has somewhat fallen. This being said, 2/3 of regions reduce the volume of housing construction. At the same time, fewer regions post industrial recession. The state of regions' budgets has not changed. As year earlier, 2/3 of regions boasted of the deficit and by the end of 2016, their number will grow. The debt volume has not declined, the list of debtladened regions remained unchanged and the debt pattern saw a reduction of tight credits at the expense of budget loans extended by the Finance Ministry.

\section{Industry and investment}

During the first 7 months of 2016, recession in industry was ongoing in 31 regions, and in manufacturing sectors - in 36 regions (in 2015 - 35 and 42 , respectively). In January-July 2016, the Vladimir region (-13\%), the Orenburg, Omsk and Chelyabinsk regions $(-5--7 \%)$ have posted the most significant recession rates among industrial regions. Strong industrial decline $(-8--12 \%)$ has also taken place in the less developed regions of the Far East (the Amur region, the Jewish Autonomous Region, and the Chukotka Autonomous Region) in the Republics of Buryatia and Mordovia.

Industrial production has been noticeably growing in several regions with large enterprises of the military-industrial complex for the second year in a row (Briansk, Rostov - 13-14\%, and Tula region - 7\%). Growth has been registered in certain regions (Kemerovo, Sakhalin regions $-8-12 \%$ ).

By contrast with industrial production, decline in investment is ongoing (4.34\% posted in Q1 2016). Investment shrank in 48 regions. It is less than was registered in 2015 when the number of regions with negative dynamic hit 56 regions (Fig. 1).

In Q1 2016, the most significant investment growth was mainly characteristic of the regions where their volume was small. This is the low base effect excluding the Leningrad and the Tyumen regions, the oil and gas producing Republics of Komi and Yakutiya. Investment geography as before is targeted at the regions with the obvious competitive advantages - resources and metropolitan areas. Leading oil and gas producing Khanty-Mansi and Yamal-Nenets Autonomous Regions have received in total $14 \%$ of all investment in the country, and together with the Tyumen region - over $16 \%$. Large metropolitan areas represent another group of leaders. Moscow boasted of $11 \%$ of the overall investment, the Moscow region and St. Petersburg $-4 \%$ each. Noticeable share of investment falls on Tatarstan (4\%), Krasnoyarsk Krai (3.5\%), and Sakhalin (2\%), which is largely owing to the production of

1 This paper was originally published in Online Monitoring of Russia's Economic Outlook No.14(32). 


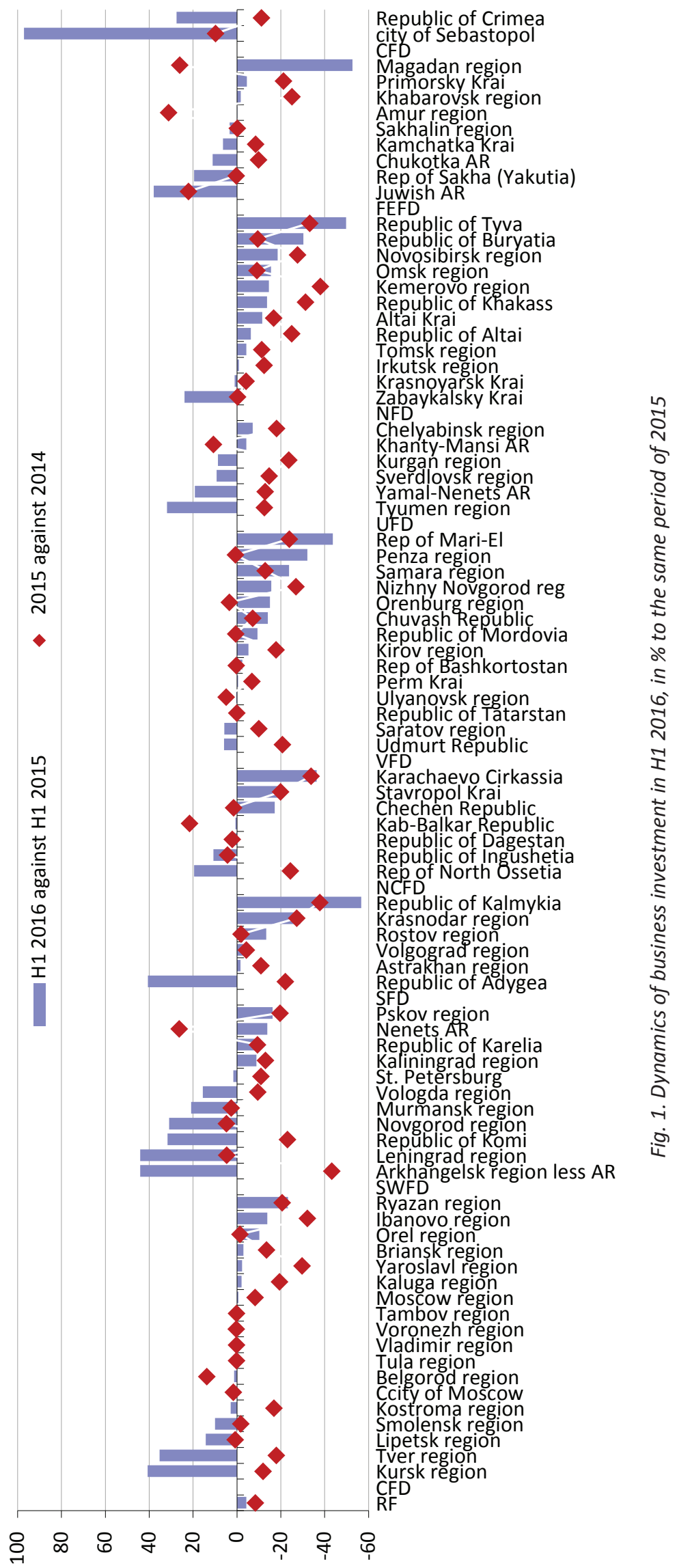


oil and gas resources. Investment has been falling for a third year in a row in the Krasnodar Krai.

\section{Housing construction and commissioning of housing}

Three-year investment decline trend is accompanied by a negative construction dynamic. Decline in the construction volume for January-July 2016 constituted $5.2 \%$ for the country as a whole and was registered in 48 regions. Among economically developed regions most drastic decline of the housing construction is being observed in the Rostov region (-36\%), the Kaluga region and Krasnodar Krai $(-24 \%)$, Nizhny Novgorod, Novosibirsk, Kemerovo regions $(-15--20 \%)$, Khanty-Mansi Autonomous Region and Chelyabinsk region (-11\%). At the same time, Moscow, St Petersburg and Republic of Tatarstan have boasted construction growth by $4-7 \%$. Some developed regions have demonstrated still higher construction growth rates (Leningrad and Samara regions, Krasnoyarsk Krai, Yamal-Nenets AR, and Yakutiya $--8--22 \%)$

Contraction of the effective demand of the population has led to a reduction of housing commissioning indices. Maximum decline was registered in H1 2016 (-9.2\%); for January-July 2016, the rates of decline were lower $(-7.4 \%)$ but this was due to the lower base effect. Contraction has taken place in 54 regions; the most indicative dynamic is registered in the regions with extensive housing construction. The situation is controversial: the Moscow region posts maximum of commissioning of housing volume (over $10 \%$ of the national level) and posts ongoing growth (+6\%), meanwhile in Moscow housing commission shrank by $28 \%$. Alternatively, in St Petersburg commissioning of housing has gone up by $9 \%$ on the back of insignificant reduction posted in the Leningrad region. Dynamic was negative in all other regions, which have significant volumes of commissioning of housing: in Krasnodar Krai, Rostov region, Republics of Tatarstan and Bashkortostan - reduction by $2-7 \%$, in Tyumen region - by one third.

\section{Social indicators}

Social indicators have also post different dynamic. According to data for May-July 2016, the unemployment level remains minimal (5.5\%). Part-time employment, which better reflects the state of the labor market in the Russian regions, hardly changed in Q2 2016. Increased rate of part-time employees post republics of Crimea, Chuvashia, Samara, Ulyanovsk, Tver and Ivanovo regions (5.2-7.3\% of the headcount in Q2 2016 with the average national rate of 3.4\%). Increased rate of employees who went on unpaid leave is registered in Chelyabinsk, Sverdlovsk regions and Republic of Mari-El (9.5-11.8\% with average rate of $7.3 \%$ ).

So far, crisis has little effect on the regional labor markets. There are different pressure points. Paramount one is the ongoing decrease of the real income of the population, which came to $4.8 \%$ in H1 2016. According to Rosstat, reduction continued in the vast majority of regions except part of regions of the Center, Tatarstan, Krasnodar Krai and several republics of the North Caucasus (data on these republics are least reliable), as well as in the Republic of Crimea (Fig. 2). A lesser decline of real income was posted in the Center and in several regions of the South, which can partly be explained by a stronger momentum in the defense and food industries, although the reliability of the regional statistics on the population income is rather relative. 


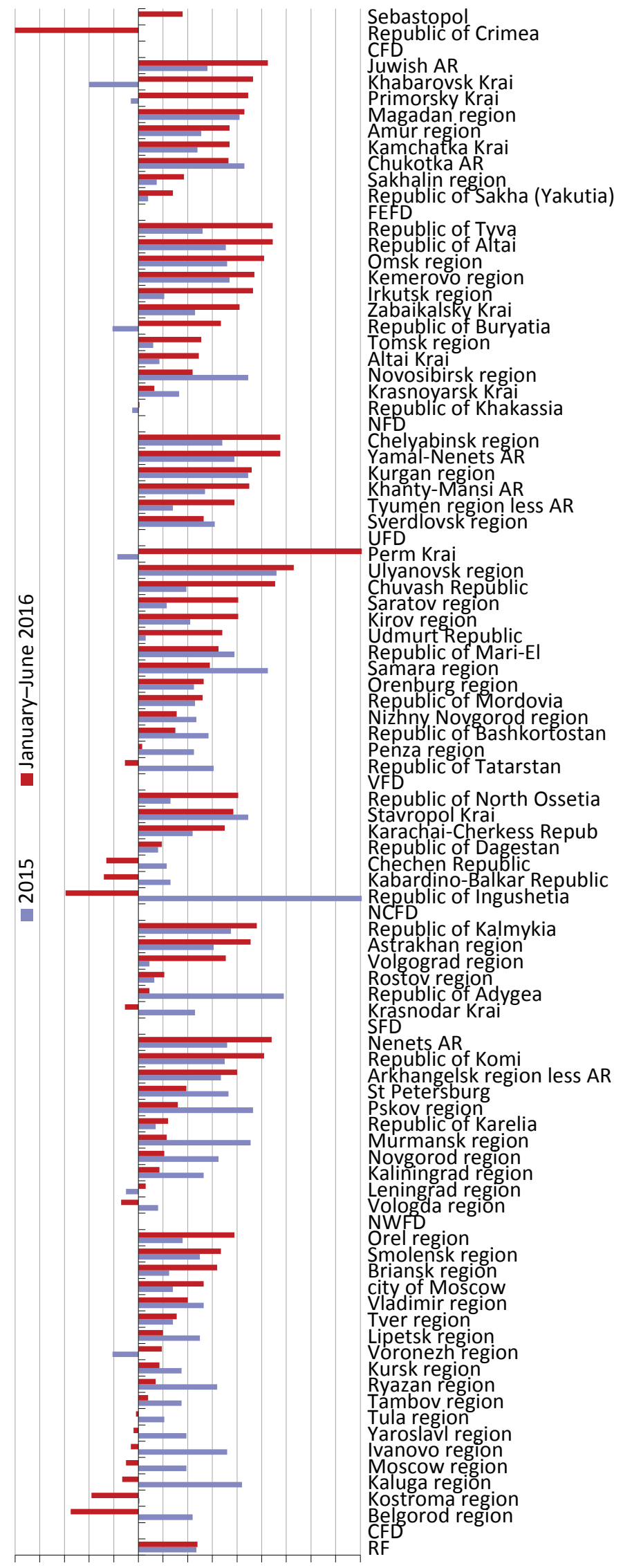

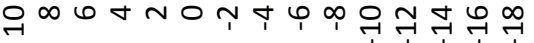


There are significant reduction rates of income posted in the regions of the East, Urals and Volga federal districts.

Consumption of the population was falling at the same rates: retail commerce decline for January-July 2016 constituted $5.6 \%$ against the same period of 2015 and embraced 75 regions. Among them are all regions of the Urals, Siberia, nearly all regions of North-West (except the Leningrad region) and Volga FD. According to statistics, especially strong reduction of the retail trade has taken place in Moscow (-12\%) and in the Oms region (-17\%), which is significantly worse dynamics of income of their population and that is why raise doubts.

\section{Budgets of regions}

In H1 2016, acute challenges of the budgets of regions remained the deficit and large debt. It is hard for the regions to avoid the deficit because the nominal revenues of the consolidated budgets have gone up by merely $2.7 \%$ (due to nearly zero growth proceeds from the income tax and reduction of transfers by $12 \%$ ), and expenses have moved up by $5.7 \%$. Spending of the regions on national economy grew faster (by $11 \%$ ). This growth was largely secured by Moscow because the capitol accounts for a quarter of the total expenditure of the regional budgets on national economy. Expenses of the Moscow budget along this item have gone up by $20 \%$ including on the public road system - by $57 \%$. Priority of provision of urban amenities represents another feature of the capitol (growth by 37\%). In H1 2016, the share of outlays on these purposes exceeded $9 \%$ of the total outlays of the budget, in other regions it comes to $1-2 \%$. As a result, Moscow accounts for $59 \%$ of the total regional budgets spending for the provision of urban amenities.

In the majority of regions, social expenses were not cut due to pending elections. There are few exceptions and Moscow is one of them. For the third year in a row, Moscow has been cutting budget spending on education (by $7 \%$ in $\mathrm{H} 12016$ ) in spite of a huge budget surplus. Spending of regional budgets on the social safety net have noticeably moved up ("social policy" item) - by $6 \%$, which is typical for the election period. Growth of spending on education (by $3 \%$ ) and health care (by $2.5 \%$ together with spending of the territorial funds of mandatory medical insurance - by $3.6 \%$ ) was minimal.

Budget deficit remains an acute issue; however, it is "disguised": in H1 2016 as in H1 2016, there was no deficit in all regions as a whole (Fig. 3). Surplus in the amount of $\mathrm{Rb} 276.6$ bn was due to a huge excess of income over expenditure in the Moscow budget ( $\mathrm{Rb} 178.7 \mathrm{bn}$ ) and Sakhalin ( $\mathrm{Rb} 61.6 \mathrm{bn}$ ) as well as significant budgetary surpluses of the Khanty-Mansi AR ( $R b 20$ bn), the Tyumen region ( $\mathrm{Rb} 17 \mathrm{bn}$ ), the Leningrad region and St Petersburg (Rb 14-15 bn each).

During H1 2016, 52 regions had budgetary deficit, 50 regions - a year earlier. Total deficit of these regions is somewhat lower than in H1 2015 (Rb 109 and 120 bn, respectively). Based on half-year data, at the end of 2016, acuteness of the problem will happen to be no less than during last year because the imbalance of the regional budgets is spurting in November-December due to growth of expenditure commitments.

As of 1 August 2016, the regional debt volume ( $R b 2.66 \mathrm{bn}$ ) has not changed in comparison with the turn of the year. However, its pattern has improved. The share of tight bank loans has shrunk from 44 to $35 \%$. The share of extended ultra-low budget loans has grown from $34 \%$ to $45 \%$ owing 


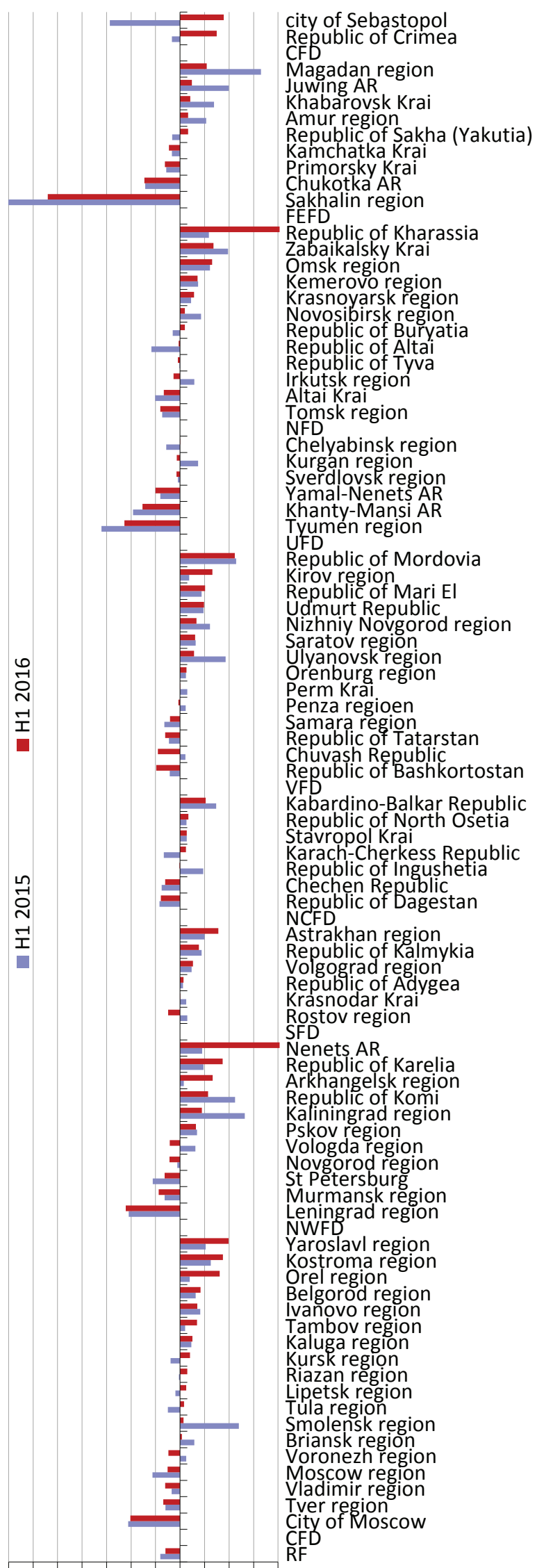

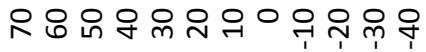


to additional lending extended by the Finance Ministry. The same improvement of the debt pattern took place during summer 2015. However, by the end of the year regions had to draw upon tight bank loans in order to meet expenditure commitments. The list of debt-ladened regions remained unchanged: the highest debt against budget revenue (fiscal and non-fiscal) have Republics of Mordovia (185\%), Khakasia and Kostroma region (122$125 \%)$, Republics of North Ossetia, Karelia, Udmurt, Smolensk and Astrakhan regions (100-111\%). Another 12 regions have debt in the range of 80 to $100 \%$ of budget revenues at average indicator of $35 \%$. The issue has been "frozen" and remains unsolved. 